\title{
Money Supply, Banking Liquidity and Stock Index Returns: Evidence from Four Major Capital Markets
}

\section{Chung $\mathrm{T}^{*}$ and Ariff $\mathrm{M}$}

Taylors University, Subang Jaya, Malaysia

\begin{abstract}
Prior studies that have examined the drivers of stock returns have mostly focussed on firm-specific factors. However, King demonstrated that firm-specific factors explain only $38 \%$ of the variation in stock prices, while the dominant driver was macroeconomic factors (52\%) with industry-related factors accounting for the remaining $10 \%$ of stock price variation. Against this background, the present study, to our knowledge, is the first attempt to model Friedman's still-unproven money-supply led banking liquidity effect and the subsequent effect on stock prices, that will be represented as stock index returns in this study. We, thereafter, proceed to build a model to connect money supply and banking liquidity to overall stock index returns. For the purpose, we apply a system of equations, and use quarterly macroeconomic data series of G-4 countries (Canada, Japan, the UK, and the US) covering a 54-year period. We control for monetary regime changes such as a shift from monetary targeting to inflation targeting, structural breaks following the global financial crisis (GFC) and monetary policy changes. To test robustness of our findings, we provide causality tests linking money supply to liquidity as well as stock index returns and earnings before applying bootstrapping method to refine the parameter estimates.
\end{abstract}

Keywords: Liquidity; Share prices; Endogeneity; Dynamic OLS; Structural break; Bootstrapping

\section{Introduction}

Prior studies that have examined the drivers of stock returns have mostly focussed on firm-specific factors. ${ }^{1}$ However, King [1] demonstrated that firm-specific factors explain only $38 \%$ of the variation in stock prices, while the dominant driver was macroeconomic factors (52\%) with industry-related factors accounting for the remaining $10 \%$ of stock price variation. Similar view was expressed 32 years later by Musílek [2], who recommended that investors need to focus mostly on price-shaping macroeconomic factors. Flannery and Protopapadakis [3] also consider macroeconomic factors as the most significant determinants of stock returns because such factors have dominant impact on future cash flow generation. Given these pointers, one would expect that research would move in the direction of examining the link between macroeconomic factors and stock returns. Curiously enough, extant research focusses on firm-specific drivers of stock price movements rather than the macroeconomic factors.

The important macroeconomic factors that influence stock price (usually measured as log change of stock prices) movements include national income, money supply led banking liquidity, inflation and interest rates. Friedman [4] suggested that money supply impacted banking liquidity, which in-turn influenced the credit creation abilities of banks, and which finally left a positive influence on asset (stock) prices. ${ }^{2}$ Though Hamilton [5] found support for this 'liquidity effect', studies by Pagan and Robertson [6], Goodfriend, [7], Lepper

${ }^{1}$ This is line with the finance literature on pricing of stock prices. Building on the work of Markowitz's (1952) mean variance portfolio, Sharpe (1964), Lintner (1965) and Mossin (1966) introduced the first accepted equilibrium asset pricing model, known widely as the CAPM. Later the multifactor model of Ross (1976) broadened the variable set to firm-relevant variables. Later Fama-French (1993) model included additional variables including macroeconomic (term structure and income growth). In our study, we are approaching the stock pricing issues from a macroeconomic angle, so we use much broader proxies as potential macro-economic factors taken from monetary economics literature.

${ }^{2} \mathrm{His}$ proposition of a negative money supply effect on interest rate has been verified in a number of studies. The empirical literature on the liquidity effect dates back at least to Cagan and Gandolfi (1969), Gibson (1970a; b), Leeper and Gordon (1992), Goodfriend (1997), Pagan and Robertson [6], Christiano, Eichenbaum and Evans [12], Hamilton [5], Thornton [13] Carpenter and Demiralp (2006) and Thornton [10]. and Gordon [8], Edmond and Weill [9] and Thornton [10] could not corroborate Friedman's liquidity proposition. ${ }^{3}$

Against this background, the present study, to our knowledge, is the first attempt to model Friedman's [4] still-unproven money-supply led banking liquidity effect and the subsequent effect on stock prices, that will be represented as stock index returns in this study. We, thereafter, proceed to build a model to connect money supply and banking liquidity to overall stock index returns. For the purpose, we apply a system of equations, and use quarterly macroeconomic data series of G-4 countries (Canada, Japan, the UK, and the US) covering a 54-year period. We control for monetary regime changes such as a shift from monetary targeting to inflation targeting, structural breaks following the global financial crisis (GFC) and monetary policy changes. To test robustness of our findings, we provide causality tests linking money supply to liquidity as well as stock index returns and earnings before applying bootstrapping method to refine the parameter estimates.

The rest of the paper is organised as follows. Section 2 provides a brief discussion of the money supply theory and its variations, focussing on the link between money supply and liquidity and thereafter between banking liquidity and stock index returns [11-13]. Section 3 explains the data preparation steps (to correct for stationarity, multicollinearity, serial correlations, heteroscedasticity, Hausman tests for random vs fixed effect modelling), and causality tests using a 3-equation system of

${ }^{3}$ The test results are not included (to save space) but are available from the authors on request.

*Corresponding author: Chung T, Taylors University, Subang Jaya, Malaysia, Tel: 6035636 2641; E-mail: TinFah.Chung@taylors.edu.my, tinfah@yahoo.com

Received April 18, 2016; Accepted May 09, 2016; Published May 29, 2016

Citation: Chung T, Ariff M (2016) Money Supply, Banking Liquidity and Stock Index Returns: Evidence from Four Major Capital Markets. Bus Eco J 7: 238. doi:10.4172/2151-6219.1000238

Copyright: (C) 2016 Chung T, et al. This is an open-access article distributed under the terms of the Creative Commons Attribution License, which permits unrestricted use, distribution, and reproduction in any medium, provided the original author and source are credited. 
equations and regression models. Section 4 presents the findings and section 5 concludes.

\section{Relevant Theory and Prior Studies}

We consider below the extant literature relating to the three constructs namely money-supply, money-supply-led liquidity and stock index returns. We thereafter consider the impact of monetary regime changes on these constructs.

Friedman [4] identified that exogenous change in money-supply exerts three types of effects on interest rates - liquidity effect, income effect and inflation effect. While the last two effects have received much attention in the monetary theory literature, the former has received limited attention. 'Despite its prominent role in conventional theories of the monetary policy transmission mechanism, there has been little evidence of a statistically significant or economically meaningful liquidity effect' [10]. The inability of the researchers to find evidence in support of a liquidity effect, is what Strongin [11] called the 'liquidity puzzle'.

\section{Money supply effect}

Though the 'liquidity (effect) puzzle' remains unresolved, monetary policy continues to be guided by the link between money supply and interest as postulated by Friedman [4]. A large body of literature has developed since 1990 to measure the magnitude of effect on market interest rates following changes in monetary policy regime. Such effects can be represented in a money demand and money supply relationship model as in Pagan and Robertson [6], shown stylistically below:

$$
\begin{aligned}
& \mathrm{m}_{\mathrm{t}}^{\mathrm{d}}=\alpha_{1}+\alpha_{2} \mathrm{r}_{\mathrm{t}}+\varepsilon_{\mathrm{t}}^{\mathrm{d}} \\
& \mathrm{m}_{\mathrm{t}}^{\mathrm{s}}=\beta_{1}+\beta_{2} \mathrm{r}_{\mathrm{t}}+\varepsilon_{\mathrm{t}}^{\mathrm{s}} \\
& \therefore \mathrm{m}_{\mathrm{t}}^{\mathrm{d}}=\mathrm{m}_{\mathrm{t}}^{\mathrm{s}}
\end{aligned}
$$

where $d$ indicates demand, $s$ supply, $m_{t}$ is the log of nominal money, $r_{t}$, is the nominal interest rate, while $\varepsilon_{t}^{d}$ and $\varepsilon_{t}^{s}$ are mutually correlated demand and supply shocks. $r_{t}$ responds to shifts in money supply engineered by varying $\beta_{1}$ and the relation $d r_{t} / d \beta_{1}=\left(\alpha_{2}-\beta_{2}\right)^{-1}$ means that the interest rate decreases when money supply increases, provided $\alpha$ ${ }_{2}<0$ and $\beta_{2}<-\alpha_{2}$. This negative reaction to interest rate changes to a rise in money supply is termed as the 'liquidity effect'. Hence, the above discussion provides a two-equation model for testing money supply and interest rates.

Changes in money supply influence firms expected earnings and consequently the stock returns. Known as the expectation effect, it takes place through the conduit of the banking sector. Money supply impacts banking sector liquidity, which in turn impacts banks' ability to lend and the lending terms. Such an impact through the banking system is more enduring than the generally short-lived expectation effect. It is so, because firms can now consider projects that they earlier found non-viable. It suggests that a proxy for earnings, such as IPI (industrial production index at the macroeconomic level) is a more appropriate variable than dividends commonly used in the individual stock pricing literature, since aggregate earnings are perfectly correlated with IPI. ${ }^{4}$

${ }^{4} \mathrm{GDP}$ and IPI were found to be cointegrated in the long-run and therefore, IPI could be used as a proxy for earnings: (to save space these results are not included).
Accordingly, the money supply-to-stock-price impact is positive when it acts through the banking channel (money supply led liquidity). ${ }^{5}$

The theoretical foundation for the money-supply led banking liquidity effect and the subsequent stock return effect is provided by the Quantity Theory of Money (QTM) and the Portfolio Theory (PT). The process of money creating liquidity and liquidity leading to credit expansion essentially alters the demand for other assets, including stocks. As and when the monetary authority makes decisions that impact money supply, it leads to changes in the prices of all assets in the market, requiring investors do rebalance their portfolios. Simple Quantity Theory of money (SQT) states:

$$
\text { M.V=P.Q }
$$

where, $\mathrm{M}$ is the total amount of money in circulation in an economy during the period, say a year; $P$ the corresponding price level; P.Q is the nominal money value of output; $V$ is the velocity of money in final expenditures; and $Q$ is an index of the real value of final expenditures. An increase in money supply is expected to increase supply of money balance, which in turn leads to excess demand for shares. It in-turn leads to rise in stock prices [14]. As money supply expands, the portfolio of desired versus actual cash holding needs adjustment. The agents who stock the excess money supply are compensated by rising price of securities as well as consumption goods and services, they sell which leads to a new equilibrium. Though the SQT and PT underpin this scenario, the link between money supply and its impact on asset prices has newer interpretations (see for example, Badarudin et al. [15]). This adjustment mechanism of asset holdings builds a positive relationship between money supply and stock index returns. Easing of money supply (quantitative easing by the US Fed in 2012-14, for example) reduces cost of capital which in-turn strengthens investment.

Similar to the assumption of Friedman [4], post-Keynesian economists too provide new insights on money being endogenously rather than exogenously determined. Consequently, before testing liquidity-stock returns link, the one between money supply and bank liquidity needs verification. The role of banking liquidity has been highlighted in both theoretical and empirical finance. The credit splurge of the 1994-04, for example, led to asset price bubbles and consequently to the GFC [1]. In summary, the money supply and liquidity link is examined before the money supply and stock returns link. Accordingly, by combining SQT and PT, we can derive the liquidity effect.

\section{Liquidity effect}

Central banks across the world base their monetary policy on the presumption that an increase (decrease) in money supply (money reserve in the banking system) would lead to a fall (rise) in policy rate (called Fed rate in the US). For the purpose, the central bank engages in Open Market Operations. The adjustment of reserves to drive the Fed funds rate relies on the presumption of 'liquidity effect' $[16,17]$. Banks hold money reserves with the central bank (called exchange settlement account in Australia), which they adjust along with other investments following monetary policy changes (called portfolio rebalancing). This in-turn impacts credit expansion (contraction) by banks which leads to larger (lower) credit demand by firms which in-turn impacts stock returns through their investment decisions.

${ }^{5}$ The theoretical framework presented by monetarists for a relationship between money supply and stock prices may be viewed from the Simple Quantity Mode (SQT) or the more sophisticated Portfolio Theory (PT). The SQT (Brunner, 1961; Friedman, 1961; and Friedman and Schwartz, 1963) states that an increase in money supply changes the equilibrium across the economy between monetary and non-monetaryy assets (for example shares) in the portfolio. 
Despite its prominent role in conventional theories about monetary policy transmission mechanism, there is limited empirical evidence to date of a statistically significant or economically meaningful moneyled liquidity effect. ${ }^{6}$ Hamilton [5] sought to develop a more convincing measure of liquidity effect by estimating the response of the federal funds rate to exogenous reserve supply shocks using daily data. However, Thornton [13] suggests that the evidence is questionable.

\section{Stock index price}

Finance literature focusses on the pricing of individual shares. The widely accepted asset pricing theory, the capital asset pricing model, (CAPM) of Sharpe [18], Lintner [19] and Mossin [20] drew from Markowitz's [21] mean variance theory. However, the basic CAPM makes some restrictive assumptions and provides poor evidence to support Markowitz theory. The substitute Arbitrage Pricing Theory (1976) also assumed that expected return of an asset and its co-variance with other random variables is linearly related. While the CAPM linked asset pricing to a single factor of beta, the APT linked it to several factors including macroeconomic factors. King's [1] approached the asset pricing issue from macroeconomic and industry perspective. Variables were derived from factor analysis of fundamental economic aggregates, such as GNP or interest rates. Chen, Roll and Ross [22] attempted to express the stock returns as a function of macroeconomic variables.

Finally, Cooper's [23] portfolio model also assumes that individuals could hold wealth in two forms, money and common stock. The marginal returns of stock assets determine the quantities of assets individuals will hold. A portfolio is said to be balanced when the marginal returns to holding these two assets are equal.

$$
M N P S_{t}^{M}-\bar{P}=M N P S_{t}^{S}+\bar{r}_{t}^{s}
$$

Where the left side is the return to money asset and the right side is the return to stock asset; $\bar{P}_{t}$ is anticipated percentage change in general price level; $\bar{r}_{t}^{*}$ is the anticipated real pecuniary return of stocks (dividend plus change in stock prices); MNPS $_{t}^{s}$ is marginal pecuniary return to the $j$-th asset (the risk of $j$-th assets is incorporated into its pecuniary returns. MNPS ${ }_{t}{ }^{M}$ is implicitly a function of demand for money except for returns on alternative assets. An underlying assumption is that the positive income effect on MNPS ${ }_{t}^{\mathrm{M}, \mathrm{S}}$ cancel each other. Thus, the difference between MNPS $_{t}{ }^{\mathrm{M}}$ and MNPS ${ }_{t}^{\mathrm{M}, \mathrm{S}}$ is primarily a function of money. In this model, money supply change induces portfolio adjustments through MNPS schedules and prices. The result is that money supply impacts to stock returns. By re-arranging this equation, it could be shown that the stock return is:

$$
\bar{r}_{t}^{s}=\left(M N P S_{t}^{M}-\bar{P}\right)-M N P S_{t}^{S}
$$

'See Pagan and Robertson (1995) Leapper and Gordon (1992) and Goodfriend (1997) for reasons why liquidity effect is hard to identify. Researchers including Bernanke and Blinder (1992), Christiano and Eichenbaum (1991, 1992a, b) have argued that the lack of empirical support is due to the Fed's preference for interest rate targeting in one form or another. Accordingly, innovations to monetary aggregates, M1, reflect shocks to money demand rather than to money supply. As a statistically significant variable that reflects the exogenous policy actions of the Fed couldn't be isolated, liquidity effect remained hidden.
Thus, Cooper [23] model is equivalent to the asset pricing model in finance. Accordingly, the relationship between the money supply and the stock prices discovered by Sprinkel [14] and Cooper [23] plays an important role in money supply leading to stock price changes (stock index returns).?

\section{Changes in monetary policy regime}

The financial systems of G-4 countries are relatively well developed and monetary policy regimes are in vogue since the 1960s. The table below summarises subsequent changes. One could identify the break in the data series using dummy variables to control for changes in monetary policy regimes while testing the maintained hypotheses on liquidity-to-stock returns (Table 1).

\section{Data, Hypothesis and Methodology}

\section{Hypotheses and methodology}

It is an empirical question whether principal economic indicators such as industrial production, inflation, interest rates, Treasury bill rate, banking liquidity and money supply are significant explanatory factors for stock returns (Hardouvellis [24], Keim [25], Litzenberger and Ramaswamy [26], King [1] found macroeconomic factors account for up to $52 \%$ and industry factors $10 \%$ of the variation in stock prices (returns).

If economic variables are significantly and consistently priced in stock returns, they should be cointegrated. If not, then, it could be concluded that the stock markets do not signal changes in real activities. We use the cointegration (a necessary condition for equilibrium in stock returns) and Granger [27] causality test to investigate the relation between stock returns and the identified macroeconomic variables and the unit root test to determine nonstationarity. If the first-differenced series of each variable are stationary, a subsequent cointegration test is performed. ${ }^{8}$ If the residuals are $\mathrm{I}(0)$, or stationary, a model can be considered to be cointegrated with a valid long run relationship. We use the Johansen and Juselius [28], maximum likelihood procedure given the difficulties with the OLS approach. It assumes endogeniety regressors and applies appropriate methods. Finally, through more powerful set of tests, we identify cointegrating vectors and evaluate the effect of various restrictions by identifying the rank of the matrix $\mathrm{P}$ in the following equation:

$$
\Delta \mathrm{X}_{\mathrm{t}}=\delta+\sum_{i=1}^{k-1} \Gamma_{i} \Delta \mathrm{X}_{\mathrm{t}-\mathrm{i}}+\Pi \mathrm{X}_{\mathrm{t}-\mathrm{k}}+\epsilon_{t}
$$

where $\mathrm{X}_{\mathrm{t}}$ is a column vector of $\mathrm{m}$ variables, $\Gamma$ and $\Pi$ represent coefficient

${ }^{7}$ However, studies by Cooper (1970), Pesando (1974), Kraft and Kraft (1977) and Rozeff (1974)) have questioned this linkage between stock prices and money supply. As liquidity surges during GFC created imbalance in both the financial and real sector, this issue which was side-tracked, re-emerged: Ariff et al. (2012).

${ }^{8}$ See also Footnote \#3. Cointegration implies that deviations from equilibrium are stationary, with finite variance, even though the series themselves are nonstationary and have infinite variance (Engle and Granger, 1987). Tests are available on request.

\begin{tabular}{|l|l|c|}
\hline Country & Event date & Start date \\
\hline Canada & Inflation targeting announced (Thiessen 1998) & $1991: 1$ \\
\hline Japan & Inflation targeting & $1991: 1$ \\
\hline United Kingdom & $\begin{array}{l}\text { Chancellor's letter to Chairman setting out new framework for monetary policy } \\
\text { (BOE diary of events) }\end{array}$ & Present \\
\hline United States & $\begin{array}{l}\text { Fed announced that it would no longer set M1 targets and moved away from } \\
\text { borrowed reserve targets }\end{array}$ & Present \\
\hline
\end{tabular}

Table 1: Changes in Monetary Policy Regime in Canada, Japan, the UK and the USA. 
matrices, $\Delta$ represents difference operator, $\mathrm{k}$ the lag length and $\delta$ is constant. This is done using methods described in [29] (Pesaran and Pesaran 1997). The rank $r$ provides the number of cointegrating vectors, a rank of 1 , for example, tests a single stationary relationship reflecting a long-run relationship. Further decomposition of the matrix $\Pi$, gives parameters of the cointegrating relationship and the adjustment coefficients of an error correction model.

Stock and Watson [30] suggest an innovative procedure for estimation of long-run equilibria via DOLS, which corrects for potential simultaneity bias among regressors. DOLS entails regressing one of the $\mathrm{I}(1)$ variables on other $\mathrm{I}(1)$ variables, the $\mathrm{I}(0)$ variables, and lags and leads of the first difference of the I(1) variables. The incorporation of the first difference variables and the associated lags and leads obviates simultaneity bias and small sample bias inherent among regressors. Standard hypothesis testing is done using robust standard errors derived via the procedure recommended by Newey and West [31].

It is hypothesized that money supply (MS) is endogenously determined by economic activity as mediated via the deposittaking institutions [15]. The literature on post-Keynesian theory on endogenous money is extensive. ${ }^{9}$ Economic activity is proxied by real gross domestic product (Y), liquidity (LQ) is endogenously determined by money supply (MS) and share prices (SP) is endogenously affected by liquidity (LQ). Money supply (MS) is also determined by share returns (DLSP), inflation (CPI), real GDP $(\mathrm{Y})$ and treasury bill rate (TBR). Liquidity is determined by real GDP (Y), money supply (MS) and lending rate (LR).

The system of equations comprising two simultaneous equations of stock returns (P) and liquidity (LQ), is solved endogenously as follows: ${ }^{10}$

$$
\begin{aligned}
& \mathrm{SP}_{\mathrm{it}}=f\left[\mathrm{LQ}_{\mathrm{it}}{ }^{+}, \mathrm{MS}_{\mathrm{it}}^{+}, \mathrm{IPI}_{\mathrm{it}}^{+}\right] \\
& \mathrm{LQ}_{\mathrm{it}}=f\left[\mathrm{MS}_{\mathrm{it}}^{+}, \mathrm{Y}_{\mathrm{it}}^{+}, \mathrm{LR}_{\mathrm{it}}^{-}\right] \\
& \mathrm{MS}_{\mathrm{it}}=f\left[\mathrm{LQ}_{\mathrm{it}}^{+}, \mathrm{Y}_{\mathrm{it}}^{+}, \mathrm{TBR}_{\mathrm{it}}, \mathrm{SP}_{\mathrm{it}}{ }^{+}, \mathrm{CPI}_{\mathrm{it}}{ }^{+}, \mathrm{CPI}(1)_{\mathrm{it}}^{+}\right]
\end{aligned}
$$

where SP is aggregate share price index, LQ is liquidity as proxied by reserve money, MS is money supply, IPI is industrial production index, $Y$ is real GDP, LR is lending rate, TRB is Treasury bill rate and CPI is inflation. All variables are in log change ratios. Countries are denoted by $i$ while $t$ denotes observations over time. The operational versions of these models are:

$$
\begin{aligned}
& \ln \mathrm{SP}_{\mathrm{it}=} \mathrm{a}_{0}+\mathrm{a}_{1} \ln \mathrm{LQ}_{\mathrm{it}}+\mathrm{a}_{2} \ln \mathrm{MS}_{\mathrm{it}}+\mathrm{a}_{3} \ln \mathrm{IPI}_{\mathrm{it}}+\mathrm{e}_{\mathrm{it}} \\
& \ln \mathrm{LQ}_{\mathrm{it}=} \mathrm{b}_{0}+\mathrm{b}_{1} \ln \mathrm{MS}_{\mathrm{it}}+\mathrm{b}_{2} \ln \mathrm{Y}_{\mathrm{it}}+\mathrm{b}_{3} \mathrm{LR}_{\mathrm{itt}} \mathrm{z}_{\mathrm{it}} \\
& \ln \mathrm{MS}_{\mathrm{it}}=\mathrm{c}_{0}+\mathrm{c}_{1} \ln \mathrm{Y}_{\mathrm{it}}+\mathrm{c}_{2} \ln \mathrm{LQ}_{\mathrm{it}} \mathrm{c}_{3} \ln \mathrm{SP}_{\mathrm{it}}+\mathrm{c}_{4} \mathrm{TBR}_{\mathrm{it}}+\mathrm{c}_{5} \ln \mathrm{CPI} \mathrm{it}_{\mathrm{it}}+\mathrm{v}_{\mathrm{it}}
\end{aligned}
$$

Two separate sets of hypotheses are developed and tested. The first set of tests is to determine whether money supply is endogenous.

$\mathrm{H}_{1}$ : MS causes GDP (suggesting money is exogenous) or there is bidirectional causality.

It is hypothesised under the alternative hypotheses that there may

${ }^{9}$ Influenced greatly by Moore in 1989 and Kaldor and Moore in 1988 developed the post-Keynesian view on money, which is today the cornerstone of the PK theory of endogenous money (Rochon, 2006). The theory posits that causality runs from bank lending to bank deposits, instead of the traditional notion that deposits create loans.

${ }^{10}$ The basis of the model in this section stems from Effa et al. (2011). Not all the variables used in that paper are used in this study because the focus of this study is on liquidity and stock returns: also see Dhakal et al. (1993) on causality between money and share prices observed directly. be unidirectional or bidirectional causality from real GDP to money supply. This hypothesis is important to verify as a pre-condition before we can embark on testing the hypotheses of whether money supply affects liquidity and that liquidity affects stock returns.

The next hypotheses are:

$\mathrm{H}_{2}$ : MS causes Liquidity: this follows from Friedman's proposition which is yet to be verified.

$\mathrm{H}_{3}$ : Liquidity causes Share Prices. This is to test the bi-directional causality.

\section{Data and variables}

Data are obtained from the datastream and the International Financial Statistics (IFS) database of the International Monetary Fund (IMF). The latter source was also used to cross-check and correct our data set. We use quarterly series over 1960:1-2013:2 (number after colon is quarter). The expected impacts of the variables in the system are shown in Table 2.

As the industrial production index (IPI) was highly correlated with national income, it could affect firm's earnings. Hence, we use the log change of IPI as a proxy for earnings in the equation for stock pricing: if IPI goes up, the earnings of the firms go up. Following Gordon and Leeper [32] we use reserve money. If the banking system has more reserves in the central bank, liquidity declines, and if it draws down, liquidity increases (Table 2).

Consequently, liquidity is inversely related to reserves, but positively related to stock index returns via the portfolio rebalancing effect by firms/individuals. For money supply, M2, values are used. ${ }^{11}$ The TBR and the bank lending rate are the domestic 3-month Treasurybill rate and lending rate respectively. The MSCI stock index values reported in Datastream is widely used for stock returns, $\mathrm{P}$, computed as log change [33-36]. The consumer price index is used as a proxy for inflation (INF). The bank lending rate (LR), deposit rates, (TBR), and real gross domestic product, (RGDP), are also obtained. All variables

\begin{tabular}{|c|c|c|c|c|c|}
\hline Variables & $\begin{array}{l}\text { Expected } \\
\text { Sign }\end{array}$ & & $\begin{array}{l}\text { Actual Sign } \\
\text { (DOLS) }\end{array}$ & \begin{tabular}{|} 
Expected \\
Sign
\end{tabular} & $\begin{array}{l}\text { Actual Sign } \\
\text { (DOLS) }\end{array}$ \\
\hline \multicolumn{4}{|l|}{ Equation 7.1: LSPRICE } & \multicolumn{2}{|c|}{ Equation 7.2: LRLQ } \\
\hline LQ & + & + & MS & + & - \\
\hline MS & + & - & $\mathrm{Y}$ & + & + \\
\hline IPI & + & - & LRate & - & - \\
\hline DUM(GFC) & + & - & DUM(GFC) & + & + \\
\hline DUM(Regime) & + & + & DUM(Regime) & + & - \\
\hline \multicolumn{6}{|l|}{ Equation7.3: LRM2 } \\
\hline LQ & + & + & & & \\
\hline Y & + & + & & & \\
\hline $\mathrm{P}$ (Stock index return) & + & - & & & \\
\hline TBRate & - & - & & & \\
\hline $\mathrm{CPI}$ & + & + & & & \\
\hline $\mathrm{CPI}(+1)$ & + & + & & & \\
\hline DUM(GFC) & + & + & & & \\
\hline
\end{tabular}
are seasonally adjusted where available and transformed to logarithmic

11 The choice of monetary aggregate and its implications on the demand for money have been discussed in Pagan and Robertson (1995) and Duca (1995) on finding the liquidity effect and for the stock market in Parhizgari (2011) on the share price effect.

Table 2: Expected and actual signs of variables in ESTIMATION. DUM (GFC) dummy for Global Finance Crisis and DUM (Regime) is dummy for regime changes. The actual signs are taken from the results to be discussed in ensuing sections. The expected sign is based on a priori hypothesis based on theory while the actual sign is taken from the DOLS regression results. 
form, with the exception of interest rates (TBR) and Lending Rate, LR [37-41].

\section{Findings}

\section{Money endogeneity causality tests}

In this sub-section, we present findings on causality to establish money endogeneity (ME) proposition for the four-country data set: Table 3. Although not directly relevant to stock index returns, it is pertinent to show that money endogeneity theory holds so as to motivate the model building within the context of monetary theory as used by Friedman [4].

The statistics presented is a summary of tests results of pairs of variables using Granger causality tests. These numbers indicate bidirectional causality for all variables - MS, GDP and Liquidity. All variables have bidirectional impact on one another except stock returns to MS and stock returns to liquidity [42-46]. In view of the reported weakness of Granger causality test on bivariate relationships, a multivariate test using three endogenous variables namely LSPRICE, LRLQ AND LRM2 was conducted in a VECM framework (TodaYamamoto, 1995) which can be applied regardless of whether the series are $\mathrm{I}(0), \mathrm{I}(1)$ or I(2) cointegrated or not in column 4 ): Table $3 .^{12}$

Causality runs in both directions in all cases, thus affirming money endogeneity. Table 4 provides summary statistics to support this. The results are about causality between stock returns and liquidity; stock returns and money supply; liquidity and money supply $[47,48]$. Tests show the variables display causality at $0.05 \%$ level. Since causality runs both ways (liquidity to share price, GDP to share price and money supply to liquidity) these can be interpreted as bidirectional causality, which supports the accommodationist version of the post-Keynesian ME proposition [15] (Tables 3-5).

Once ME is verified, we could present our findings on liquidity and on stock index return hypotheses. This is further confirmed from the results of Table 5 using the Toda Yamamoto VECM multivariate causality tests. All the 3 panels in Table 4 showed that the variables tested displayed causality is significant at the $5 \%$ level of rejecting the null hypothesis [49-51].

\section{Descriptive statistics}

We discuss descriptive statistics, followed by the data transformation procedures, results of single equation country results, the results from the more robust DOLS regressions, and further robustness test result using bootstrapping [52-54].

${ }^{12}$ Test statistics to support the conclusions and data transformation tests are available on request.

\begin{tabular}{|c|c|c|c|}
\hline \multicolumn{2}{|c|}{$\begin{array}{l}\text { Money Endogeneity Test Results } \\
\text { Monetarist Accommodationist }\end{array}$} & $\begin{array}{c}\text { Panel Data on G4 } \\
\text { Countries }\end{array}$ & $\begin{array}{l}\text { Panel Data on G4 } \\
\text { Countries (Using } \\
\text { Toda Yamamoto) }\end{array}$ \\
\hline MS --> Y & $Y<-->M S$ & MS --> Y & $M S<-->Y$ \\
\hline$M S-->L Q$ & $M S<-->L Q$ & $M S<-->L Q$ & $M S<-->L Q$ \\
\hline MS --> SP & $M S<-->S P$ & $M S-->S P$ & $M S<-->S P$ \\
\hline LQ --> Y & $L Q<-->Y$ & $Y$--> LQ & $L Q<-->Y$ \\
\hline$S P \Rightarrow Y$ & $L Q<-->Y$ & $S P<-->Y$ & $S P<-->Y$ \\
\hline SP --> LQ & $L Q<-->Y$ & $S P<-->L Q$ & $S P<-->L Q$ \\
\hline
\end{tabular}

Table 3: Granger causality on money endogeneity and panel regression results. Column 3 shows the results of Granger bivariate causality tests using the pane data on G-4 countries while Column 4 are the results from the Toda Yamamoto VECM multivariate model. Stock index returns are shown as SP.

\begin{tabular}{|l|c|c|c|}
\hline Sample: 1832 & \\
\hline Lags: 5 \\
\hline Null Hypothesis: & Obs & F-Statistic & Prob. \\
\hline LRLQ does not Granger Cause LSPRICE & 742 & 9.34774 & 0.0001 \\
\hline LSPRICE does not Granger Cause LRLQ & & 2.11624 & 0.0616 \\
\hline LRM2 does not Granger Cause LSPRICE & 769 & 3.59581 & 0.0032 \\
\hline LSPRICE does not Granger Cause LRM2 & & 0.96249 & 0.4399 \\
\hline LRGDP does not Granger Cause LSPRICE & 801 & 5.74312 & 0.0001 \\
\hline LSPRICE does not Granger Cause LRGDP & & 24.5287 & 0.0001 \\
\hline LRM2 does not Granger Cause LRLQ & 710 & 3.64781 & 0.0029 \\
\hline LRLQ does not Granger Cause LRM2 & & 2.25999 & 0.0469 \\
\hline LRGDP does not Granger Cause LRLQ & 742 & 2.54850 & 0.0268 \\
\hline LRLQ does not Granger Cause LRGDP & & 1.03017 & 0.3986 \\
\hline LRGDP does not Granger Cause LRM2 & 769 & 0.64035 & 0.6690 \\
\hline LRM2 does not Granger Cause LRGDP & & 2.64680 & 0.0221 \\
\hline
\end{tabular}

Table 4: Granger Bivariate Causality Results for Data on Canada, Japan, the UK and USA. The first "L" in each variable denotes log change: RGDP is real income as proxy for income, RLQ is liquidity as proxy by reserve money, RM2 is proxy for money supply M2 and Stock index returns are shown as SPRICE in this table. The F-statistics obtained are used to evaluate whether to accept the null hypothesis of no Granger causality. Any prob. value of $>0.05$ will result in acceptance of null hypothesis.

\begin{tabular}{|c|c|c|c|}
\hline \multicolumn{4}{|c|}{ Sample: 1960Q1 2011Q4 } \\
\hline \multicolumn{4}{|c|}{ Included observations: $\mathbf{7 1 0}$} \\
\hline \multicolumn{4}{|c|}{ Dependent variable: SPRICE=stock index returns } \\
\hline Excluded & Chi-sq & df & Prob. \\
\hline LRLQ & 42.55194 & 5 & 0 \\
\hline LRM2 & 17.2475 & 5 & 0.0041 \\
\hline All & 63.32206 & 10 & 0 \\
\hline \multicolumn{4}{|c|}{ Dependent variable: LRLQ } \\
\hline Excluded & Chi-sq & df & Prob. \\
\hline LSPRICE & 12.30395 & 5 & 0.0309 \\
\hline LRM2 & 20.04474 & 5 & 0.0012 \\
\hline All & 30.73359 & 10 & 0.0006 \\
\hline \multicolumn{4}{|c|}{ Dependent variable: LRM2 } \\
\hline Excluded & Chi-sq & $d f$ & Prob. \\
\hline LSPRICE & 7.394611 & 5 & 0.1929 \\
\hline LRLQ & 13.93748 & 5 & 0.016 \\
\hline All & 18.73326 & 10 & 0.0438 \\
\hline
\end{tabular}

Table 5: Robustness testing with Toda Yamamoto VECM multivariate causality tests. The first "L" in each variable denotes log change: SPRICE is share price index, RLQ is liquidity as proxy by reserve money and RM2 is proxy for money supply M2 and. The Wald Chi-square statistics obtained are used to evaluate whether to accept or reject the null hypothesis. Any prob. value of $<0.05$ show that there is strong causation running from LRLQ and LRM2 to LSPRICE and in the first panel as the asymptotic chi-square $\left(X^{2}\right)$ is rejected.

We present the main results obtained from first using the single equation and then a system of equations model where the appropriate factors are entered as three equations. The Table 6 is a summary of descriptive statistics of the variables used in the regression (single equations and Stock Watson DOLS equations) (Table 6).

The variables are first differenced and computed as ratio relative to prior observation. The Jarque-Bera (JB) test indicates that all variables are not normal $(J B>5.9$ and $p$ value of $<0.05$ rejecting the null hypothesis of normality). Most of these variables are skewed $(>0$, for normality should be close to 0 ). A quick read of the values of these variables suggest that these are as one would expect in the panel of G-4 economies. For example, the average Treasury rate over the test period in the industrial economies of G-4 countries is $5.9 \%$ and the lending rate is $7 \%$. Inflation (mean of difference in log CPI) has a mean of $1.1 \%$ 


\begin{tabular}{|c|c|c|c|c|c|c|c|c|c|}
\hline & LCPI & LR & LRGDP & LRIPI & LRLQ & LRM2 & LSPRICE & DLSPRICE & TBR \\
\hline Mean & 3.94 & 6.98 & 4.02 & 0.21 & -0.41 & 3.53 & 3.33 & 0.02 & 5.94 \\
\hline Median & 4.19 & 6.57 & 4.07 & 0.012 & -1.01 & 3.20 & 3.40 & 0.02 & 5.64 \\
\hline Maximum & 4.76 & 21.67 & 4.67 & 1.78 & 2.78 & 9.07 & 5.38 & 0.37 & 20.15 \\
\hline Minimum & 2.34 & 0.157 & 2.41 & -0.41 & -2.92 & -0.74 & 1.03 & -0.35 & 0.00 \\
\hline Std. Dev. & 0.67 & 3.48 & 0.45 & 0.44 & 1.30 & 2.93 & 1.08 & 0.08 & 3.53 \\
\hline Skewness & -0.69 & 0.80 & -0.79 & 1.78 & 0.66 & 0.67 & 0.006 & -0.56 & 0.64 \\
\hline Kurtosis & 2.13 & 3.88 & 3.48 & 6.013 & 2.09 & 2.09 & 1.63 & 5.60 & 3.49 \\
\hline Jarque-Bera & 77.68 & 96.37 & 80.43 & 632.69 & 73.95 & 76.32 & 55.32 & 233.38 & 54.77 \\
\hline
\end{tabular}

Table 6: Descriptive Statistics of the Panel Variables of Canada, Japan, the UK and the USA. The first "L" in each variable denotes log change: GDP is real income as proxy for income, LQ is liquidity as proxy by reserve money, M2 is proxy for money supply M2, CPI is consumer price index for inflation, IPI is industrial production index, LR is lending rate, and TBR is Treasury yields. DLSPRICE is change in log of share price denoting share price returns. Std. Dev. is standard deviation. $L$ indicates log change of variables.

\begin{tabular}{|c|c|c|c|c|c|c|c|c|}
\hline \multicolumn{3}{|c|}{ First Equation: Share Price Equation (Eq 7.1) } & \multicolumn{3}{|c|}{ Second Equation: Liquidity (Eq. 7.2) } & \multicolumn{3}{|c|}{ Third Equation: Money Supply (Eq. 7.3) } \\
\hline DV is Share Price (SP) & OLS & DOLS & DV is Liquidity & OLS & DOLS & DV is Money Supply & OLS & DOLS \\
\hline \multicolumn{3}{|c|}{ (Coefficients with t-statistics in brackets) } & \multicolumn{3}{|c|}{ (Coefficients with t-statistics in brackets) } & \multicolumn{2}{|c|}{ (Coefficients with t-statistics in brackets) } & \\
\hline C & $3.43^{* *}(-65.85)$ & - & $\mathrm{C}$ & $-0.37(-0.78)$ & - & C & $-1.28(-0.94)$ & - \\
\hline \multirow[t]{2}{*}{ LRLQ } & $-0.04^{*}$ & $1.19^{* * *}$ & LRM2 & $0.05^{* * *}$ & $-0.25^{\star *}$ & LRGDP & $1.20^{* * *}$ & $1.44^{* * *}$ \\
\hline & $(-1.93)$ & $(-3.30)$ & & $(-2.68)$ & $(-2.12)$ & & $(-2.67)$ & $(-4.93)$ \\
\hline \multirow[t]{2}{*}{ LRM2 } & $-0.03^{\star \star *}$ & $-0.91^{* * *}$ & LRGDP & 0.09 & $3.21^{* * \star}$ & LRLQ & 0.13 & $0.46^{* \star *}$ \\
\hline & $(-3.03)$ & $(-2.25)$ & & $(-0.76)$ & $(-10.67)$ & & $(-1.51)$ & $(-4.23)$ \\
\hline \multirow[t]{2}{*}{ LRIPI } & 0.85 & -0.03 & LRate & $-0.10^{\star \star *}$ & $-0.04^{* * *}$ & LSPRICE & 0.16 & $-0.13^{* * *}$ \\
\hline & $(-0.74)$ & $(-0.13)$ & & $(-6.99)$ & $(-9.84)$ & & $(-0.52)$ & $(-4.20)$ \\
\hline \multirow[t]{2}{*}{ LRIPI (-1) } & $-2.07^{*}$ & - & DUM (GFC) & $0.61^{* *}$ & $0.52^{\star \star \star}$ & TBRate & $0.26^{\star * *}$ & -0.004 \\
\hline & $(-1.80)$ & & & $(-2.31)$ & $(-5.54)$ & & $(-6.13)$ & $(-0.67)$ \\
\hline \multirow[t]{2}{*}{ DUM (GFC) } & $1.42^{* \star *}$ & -0.34 & DUM (Regime) & $0.44^{* * *}$ & -0.02 & LCPI & $30.65^{\star * *}$ & $0.41^{* * *}$ \\
\hline & $(-9.46)$ & $(-0.32)$ & & $(-3.38)$ & $(-0.51)$ & & $(-2.98)$ & $(-5.47)$ \\
\hline \multirow[t]{2}{*}{ DUM (Regime) } & $0.80^{* * *}$ & $0.29^{* *}$ & Model Parameters & & & DUM (GFC) & $2.59^{* *}$ & 0.38 \\
\hline & $(-10.93)$ & $(-2.26)$ & Adjusted $\mathrm{R}^{2}$ & 0.1558 & 0.9993 & & $(-4.51)$ & $(-1.55)$ \\
\hline Model Parameters & & & Std Error & 1.1929 & 0.0353 & DUM (Regime) & $2.35^{\star \star \star}$ & 0.04 \\
\hline Adjusted $\mathrm{R}^{2}$ & 0.5776 & 0.9888 & Mean & -0.4159 & 0.3517 & & $(-8.26)$ & $(-1.46)$ \\
\hline Std Error & 0.7209 & 0.1036 & SD of dep var & 1.2984 & 1.3092 & Model Parameters & & \\
\hline Mean & 3.2672 & 3.2022 & Sum of Square Res & 993.36 & 0.7235 & Adjusted $\mathrm{R}^{2}$ & 0.2102 & 0.9999 \\
\hline SD of dep var & 1.1094 & 0.9714 & Long-run variance & & 0.01 & Std Error & 2.6177 & 0.0197 \\
\hline Sum of Square Res & 374.27 & 6.3889 & & & & Mean & 3.4105 & 5.8159 \\
\hline \multirow[t]{3}{*}{ Long-run Variance } & & 0.1302 & & & & SD of dep var & 2.9455 & 2.2902 \\
\hline & & & & & & Sum of Square Res & 4926.8 & 0.2119 \\
\hline & & & & & & Long-run Variance & & 0.0052 \\
\hline
\end{tabular}

Note: ***, **, and *denote significance at the $0.01,0.05$ and 0.10 per cent probability levels respectively.

Table 7: Results of G-4 Countries Estimation Using Single Equations. The first "L" in each variable denotes log change: GDP is real income as proxy for income, LQ is liquidity as proxy by reserve money, M2 is proxy for money supply M2, CPI is consumer price index for inflation, LR is lending rate, and TBR is Treasury yields. DUM is for dummy variables for the indicated conditions.

or annualised rate of $4.4 \%$. The mean of difference in LSPRICE or the share price returns is $1.5 \%$ or annualised rate of $5.9 \%$ over $1960-2012$, with a maximum return of $37 \%$ achieved during the bull phase and a minimum of $35 \%$ during the bear phase of the market correction [55].

\section{DOLS Results using panel data}

We discuss the results from single equation first before presenting the DOLS results. It is hypothesised that money supply causes liquidity change and that liquidity in turn causes stock prices to change. The statistics presented in Table 7 indicate that the dependent variable in the first equation-stock index return is represented as stock price - is determined by reserve money (liquidity or LQ), also by money supply, MS and the proxy for earnings IPI. All the variables are significant [56]. The liquidity impact on money supply in the third equation is economically significant affirming that bank reserves increases at the central bank, which leads to a decline in money supply. In the second equation, liquidity is determined by money supply, lending rate, LR and income entered as real GDP. All the variables except money supply (LRM2) and lending rate (LR) are significant.

Money supply in the third equation is determined by income (RGDP), reserve money (LQ), share price (SP), Treasury bill rate (TBR) and inflation (CPI). The significant relation between LQ and money is as per Friedman [4] proposition - a significant confirmation of the liquidity hypothesis [56]. Except for stock index returns, all the variables are significant. The income elasticity of money is less than one, $0.62 \%$.

\section{Results from cointegration tests using stock and watson DOLS}

The results presented above are from the four country data runs by each equation at a time. We now present the results from a more reliable DOLS cointegration method which is robust to various departures from standard regression assumptions in terms of residual correlation, hetroscedasticity, misspecification of functional form and 
non-normality of residuals, so the resulting findings are reliable [57]. The results are estimated with up to $\mathrm{j}= \pm 4$ leads and lags (insignificant lags and leads were dropped). Table 8 provides a summary of results.

The results on stock index return variables are presented in the first part of the table. The statistics on stock index indicate that stock index returns (represented as $\mathrm{P}$ ) is significantly influenced by banking reserve money LQ (liquidity) with a coefficient of 1.19, money supply LM2 with a coefficient of -0.91 and earnings of firms, LRIPI, a control variable, is not significant. The control variable for the GFC is negative and significant as the monetary regimes shifted (DUMRegimes). All the variables except IPI are significant [58].

In the test results from second equation (Eq. 7.2), liquidity is influenced by money supply (LRM2) with a coefficient of -0.25 as suggested by Friedman [4], that is, money supply M2 increases leads to downward interest rates, which in turn leads to increased banking liquidity and vice versa. The real GDP (proxy for income) has a coefficient of 3.21, and the lending rate LR has a coefficient of -0.04 . All the variables are significant. Going by the adjusted R-squared value, the model fit is considered appropriate. The financial crisis and the regime change are found to be significant factors affecting liquidity (Table 8).

The results on the third equation (Eq. 7.3) are summarised in the third part of the Table 8. Except for TBR, all the variables are significant. Most of the variables also show the expected signs.

Table 2 specifies the signs that were expected for each coefficient and the actual sign obtained. Five signs are different from the expected signs: The money supply (MS) equation (7.3) and the share price (P) equation (7.1). The dummy variables which represent breaks for monetary regime changes from macroeconomic aggregates to inflation targeting (Canada: 1991:1 to 2011:4; Japan: 1999:1 to 2011:4; UK: 1992:4 to 2011:4; US 1987:1 to 2011:4) and the effect of global financial crisis in 2007:2 to 2009:4 were found to be significant as expected.

\section{Robustness Test Results Using Bootstrapping}

The robustness test results obtained from bootstrapping are presented in Table 9. Bootstrapping is meant to enhance the robustness of the results by quasi-simulation procedure. Despite the fact that DOLS in itself is a robust methodology, applying robustness procedures helped us to see if some of the observed departures from theory predictions are restored and improved. Indeed, the results are much improved, and the model fit is still quite good (Table 9).

In the first equation for stock index returns, there is considerable improvement in the parameters. The adjusted $\mathrm{R}$-squared values are lower as often happens in bootstrapping results. GFC is significant as before. The liquidity effect is about half that observed in the DOLS results, meaning that the quasi-simulation estimates from bootstrapping is a more reliable average effect of banking liquidity on stock index returns.

On the banking liquidity results too there are some improvements. Money supply effect is less pronounced at -0.60 (recall reserves have a negative effect) than in the DOLS result, but is still significant. Lending rate - a key variable for supply of bank credit - has a slightly larger and significant effect with a coefficient of -0.11 , and significant. The adjusted R-squared ratio is lower, as in all bootstrapping results.

Examining the results for equation 4 on money supply, we note some improvements. All variables are now significant with changed coefficients. The adjusted R-squared ratio is lower, as usual. The stock

\begin{tabular}{|c|c|c|c|c|c|c|c|c|}
\hline \multicolumn{3}{|c|}{ Dependent Variable Stock Price } & \multicolumn{3}{|c|}{ Dependent Variable Liquidity } & \multicolumn{3}{|c|}{ Dependent Variable Money Supply } \\
\hline \multicolumn{3}{|c|}{ Variable Coefficient t-Statistic } & \multicolumn{3}{|c|}{ Variable Coefficient t-Statistic } & \multicolumn{3}{|c|}{ Variable Coefficient t-Statistic } \\
\hline LRLQ & 1.19 & $3.30^{* * *}$ & LRM2 & -0.25 & $-2.12^{* *}$ & LRGDP & 1.44 & $4.93^{* * *}$ \\
\hline LRM2 & -0.91 & $-2.25^{\star \star}$ & LRGDP & 3.21 & $10.67^{* * *}$ & LRLQ & 0.46 & $4.23^{\star \star *}$ \\
\hline LRIPI & -0.03 & -0.13 & LR & -0.04 & $-9.84^{\star * *}$ & LSPRICE & -0.13 & $-4.20^{* * *}$ \\
\hline DUMGFC & -0.34 & -0.32 & DUMGFC & 0.52 & $5.54^{* * *}$ & TBR & -0.004 & -0.67 \\
\hline \multirow[t]{3}{*}{ DUMRegime } & 0.29 & $2.26^{\star *}$ & DUMRegime & -0.02 & -0.51 & LCPI & 0.41 & $5.47^{* * *}$ \\
\hline & & & & & & DUM GFC & 0.38 & $1.55^{*}$ \\
\hline & & & & & & DUM1Regime & 0.04 & 1.46 \\
\hline \multicolumn{3}{|c|}{ R-sq=0.99; adj R-sq=0.99; Fixd Eff } & \multicolumn{3}{|c|}{ R-sq=0.99; adj R-sq=0.99; Fixed Eff } & \multicolumn{3}{|c|}{ R-sq=0.98; adjR-sq=0.97; Fixed Eff } \\
\hline
\end{tabular}

Note: ${ }^{* * *},{ }^{* *}$, and ${ }^{*}$ denote significance at the $0.01,0.05$ and 0.10 per cent probability levels respectively.

Table 8: Results of DOLS Estimation from System of Equations for Canada, Japan, the UK and the USA. The first "L" in each variable denotes log change on indicated variables: GDP is real proxy for income, LQ is liquidity for banking reserves at central bank, M2 is proxy for money supply, CPI is price index for inflation, LR is bank lending rate, and TBR is Treasury yields. DUMGFC is for dummy variable for financial crisis years in 2007-2009; DUMRegime is dummy for monetary regimes. In the stock price equation, IPI is industrial production index, a proxy for earnings of firms; LR is lending rate; and LPRICE is stock index returns.

\begin{tabular}{|c|c|c|c|c|c|c|c|c|}
\hline \multicolumn{3}{|c|}{ Dependent Variable Stock Price } & \multicolumn{3}{|c|}{ Dependent Variable Liquidity } & \multicolumn{3}{|c|}{ Dependent Variable Money Supply } \\
\hline \multicolumn{3}{|c|}{ Variable Coefficient t-Statistic } & \multicolumn{3}{|c|}{ Variable Coefficient t-Statistic } & \multicolumn{3}{|c|}{ Variable Coefficient t-Statistic } \\
\hline Constant & 3.06 & $47.00^{* * *}$ & Constant & -0.70 & 1.21 & Constant & -0.78 & -0.68 \\
\hline LRLQ & 1.09 & $-5.87^{\star \star \star}$ & LRM2 & 0.60 & $7.48^{* * *}$ & LRGDP & 0.99 & $2.62^{\star * *}$ \\
\hline LRM2 & -0.02 & $-2.72^{\star \star *}$ & LRGDP & 0.19 & 1.21 & LRLQ & 0.24 & $5.19^{\star \star *}$ \\
\hline LRIPI & 0.26 & 2.02 ** & LR & -0.11 & $-6.11^{* * *}$ & LSPRICE & 0.32 & $1.87^{*}$ \\
\hline DUMGFC & 0.52 & $8.08^{\star * *}$ & DUMGFC & 0.29 & 1.05 & TBR & -0.19 & $7.54^{\star * *}$ \\
\hline DUMRegime & 1.25 & $23.45^{\star * *}$ & DUMRegime & 0.11 & 0.62 & LCPI & 32.0610 .76 & $3.32^{\star * *}$ \\
\hline & & & & & & DUM GFC & 1.07 & $1.82^{*}$ \\
\hline & & & & & & DUM1Regime & & $5.83^{* * *}$ \\
\hline \multicolumn{3}{|c|}{ R-sq=0.71; adj R-sq=0.71; Fixd Eff } & \multicolumn{3}{|c|}{ R-sq=0.75; adj R-sq=0.74; Fixed Eff } & \multicolumn{3}{|c|}{ R-sq=0.76; adjR-sq=0.75; Fixed Eff } \\
\hline
\end{tabular}

Note: ***, **, and *denote significance at the $0.01,0.05$ and 0.10 per cent probability levels respectively.

Table 9: Results of robustness testing from bootstrapping method. The values for the constants are reported in this table. The first "L" in each variable denotes log change on indicated variables: GDP is real proxy for income, LQ is liquidity for banking reserves at central bank, M2 is proxy for money supply, CPI is price index for inflation, LR is bank lending rate, and TBR is Treasury yields. DUMGFC is for dummy variable for financial crisis years in 2007-2009; DUMRegime is dummy for monetary regimes. In the stock price equation, IPI is industrial production index a proxy for earnings of firms; LR is lending rate; LSPRICE is stock index returns. Bootstrapping by iterations of the results in Table 6, produces more accurate parameter estimations, so it is an excellent robustness test for this study. 
index return is significantly affected by money. In the equation, stock index return is theorized as having an effect from liquidity arising from money supply. In the DOLS results, the sign was wrong but in the bootstrapped results it is positive. All other key variables, are significant in the bootstrapped results compared to the results from DOLS. Overall, we have much improved findings from bootstrapping.

\section{Conclusion}

This paper is about the impact of money supply on liquidity and in turn its impact on stock index returns. The findings contribute to the literature by examining the hitherto unverified effect of money supply on liquidity. Importantly, we adopt all the required refinements to obtain robust parameter estimates and for the purpose use a threeequation system developed in this study. Accordingly, the evidence sheds new light on the money supply and stock index returns literature.

We use quarterly series of panel data for Canada, US, UK and Japan for the period 1960:1 to 2013:4 and by adding an asset pricing equation to Friedman [4] propositions, we test for a liquidity-credit surge effect on stock index returns. Further, by using controls for monetary regime changes and the effect of GFC by specifying dummy variables, errors in estimations are avoided. The results suggest that money supply is endogenous and that there is bidirectional causality from money to interest rate as confirmed by prior studies.

That there is a liquidity effect helps to confirm Friedman's proposition on money supply effect on banking liquidity. The test on the link between liquidity's flow-through impacts on stock index led to establishing a credible link from banking liquidity and stock index returns. It shows strong influence of money supply and liquidity in the above countries.

The study has limitation in terms of the use of quarterly series since GDP data are only available as quarterly series. In our opinion, a major contribution of this paper is the verification of Friedman's liquidity effect arising from money supply, after controlling for other factor effects: prior tests attempted to do this with daily data without success. A further contribution is the impact of banking liquidity changes measured by bank reserves with the central banks on the stock index returns. Furthermore, the use of Dynamic Ordinary Least Squares modelling for four key economies with broadly similar financial environments adds a unique dimension. The robustness of the reported findings is cross-checked using bootstrapping.

\section{References}

1. King BF (1966) Market and Industry Factors in Stock Price Behaviour. Journal of Business 39: 139-190.

2. Musilek $P$ (1997) Changes in macroeconomic variables and stock prices Finance and Credit 47: 3

3. Flannery MJ, Protopapadakis A (2002) Macroeconomic Factors do Influence Aggregate Stock Returns. Review of Financial Studies 15: 751-782.

4. Friedman M (1969) Factors Affecting the Level of Interest Rates. In Proceeding of the 1968 Conference on Saving and Residential Financing. Chicago: United States Saving and Loan League 11-27.

5. Hamilton JD (1997) Measuring the Liquidity Effect. American Economic Review 87: 80-97.

6. Pagan AR, Robertson JC (1995) Resolving the Liquidity Effect. Federal Reserve Bank of St. Louis Review 77: 33-54.

7. Goodfriend M (1997) A Framework for the Analysis of Moderate Inflations. Journal of Monetary Economics 39: 45-65.

8. Gordon DB, Leeper EM (2002) The Price Level, the Quantity Theory of Money, and the Fiscal Theory of the Price Level. NBER Working Paper, National Bureau of Economic Research.

9. Edmond C, Weill PO (2005) Models of the Liquidity Effect. The New Palgrave Dictionary of Economics, Palgrave Macmillan.

10. Thornton DL (2007) Open Market Operations and the Federal Funds Rate. In Open Market Operations and the Financial Markets, the Bank of Finland. Reprinted in the Federal Reserve Bank of St. Louis Review 89: 549-572.

11. Strongin S (1995) The Identification of Monetary Policy Disturbances: Explaining the Liquidity Puzzle. Journal of Monetary Economics 35: 463-497.

12. Thornton DL (2001) The Federal Reserve's Operating Procedure, Nonborrowed Reserves, Borrowed Reserves and the Liquidity $\mathrm{E} \square$ ect. Journal of Banking and Finance 25: 1717-1739.

13. Christiano LJ, Eichenbaum M, Evans CL (1996) The Effects of Monetary Policy Shocks: Evidence from the Flow of Funds. Review of Economics and Statistics 78: 16-34

14. Sprinkel BW (1964) Money and Stock Prices. New York: Richard D. Irwin, Homewood, III.

15. Badarudin E, Ariff M, Khalid A (2013) Post Keynesian money endogeneity evidence in G-7 economies. Journal of International Money \& Finance 33: 146162

16. Ariff M, Farrar J, Khalid AM (2012) Regulatory Failure and Global Financia Crisis. Chelthenham; Northmpton: Edward Elgar Publishing Ltd. UK and USA.

17. Carpenter S, Demiralp S (2006) The Liquidity Effect in the Federal Funds Market: Evidence from Daily Open Market Operations. Journal of Money, Credit, and Banking 38: 901-920.

18. Sharpe WF (1964) Capital Asset Prices: A Theory of Market Equilibrium under Conditions of Risk. Journal of Finance 19: 425-442.

19. Lintner J (1965) The Evaluation of Risky Assets and the Selection of Risky Investments in Stock Portfolios and Capital Budgets. Review of Economics and Statistics 47: 13-37.

20. Mossin J (1966) Equilibrium in Capital Asset Markets. Econometrica 34: 768783

21. Markowitz H (1952) Portfolio Selection. Journal of Finance 7: 77-91.

22. Roll R, Ross S (1980) An Empirical Investigation of the Arbitrage Pricing Theory. Journal of Finance 35: 1073-1103.

23. Cooper RVL (1974) Efficient Capital Markets and the Quantity Theory of Money. Journal of Finance 30: 338-341.

24. Hardouvelis GA (1987) Macroeconomic Information and Stock Prices. Journal of Economics and Business 39: 131-140.

25. Keim DB (1985) Dividend Yields and Stock Returns: Implications of Abnorma January Returns. Journal of Financial Economics 14: 473-489.

26. Litzenberger RH, Ramaswamy K (1982) The Effects of Dividends on Common Stock Prices: Tax Effects or Information Effects? Journal of Finance 37 429-443.

27. Granger CWJ (1988) Some Recent Development in a Concept of Causality Journal of Econometrics 39: 199-211.

28. Johansen S, Juselius K (1990) The Full Information Maximum Likelihood Procedure for Inference on Cointegration With Applications To The Demand For Money. Oxford Bulletin of Economics and Statistics 52: 169-210.

29. Pesaran MH, Pesaran B (1997) Working with Microfit 4.0: An interactive econometric software package (DOS and Windows versions). Oxford: Oxford University Press

30. Stock JH, Watson M (1993) A simple estimator of cointegrating vectors in higher Order integrated systems. Econometrica 61: 783-820.

31. Newey WK, West KD (1987) A simple, positive semidefinite, heteroskedasticity and autocorrelation consistent covariance matrix. Econometrica 55: 703-708.

32. Leeper EM, Gordon DB (1992) In Search of the Liquidity Effect. Journal of Monetary Economics 29: 341-369.

33. Brunner K (1961) Some Major Problems in Monetary Theory. American Economic Review 51: 47-56.

34. Cagan P, Gandolfi A (1969) The Lag in Monetary Policy as Implied by the Time 
Citation: Chung T, Ariff M (2016) Money Supply, Banking Liquidity and Stock Index Returns: Evidence from Four Major Capital Markets. Bus Eco J 7: 238. doi:10.4172/2151-6219.1000238

Page 9 of 9

Pattern of Monetary Effects on Interest Rates. American Economic Review 59: 277-284.

35. Chen NF, Roll R, Ross SA (1986) Economic Forces and the Stock Market. Journal of Business 59: 383-403.

36. Christiano LJ, Eichenbaum M (1992a) Liquidity Effects and the Monetary Transmission Mechanism. The American Economic Review 89: 346-53.

37. Christiano LJ, Eichenbaum M (1992) Liquidity Effects, Monetary Policy and the Business Cycle. National Bureau of Economic Research.

38. Dhakal D, Kandil M, Sharma SC (1993) Causality between the Money Supply and Share Prices: a VAR Investigation. Quarterly Journal of Business and Economics 32: 52-74.

39. Duca JV (1995) Should Bond Funds be added to M2?. Journal of Banking and Finance 19: 131-152.

40. Effa B (2011) Endogeneous Money Supply and Bank Stock Returns: Empirical evidence Using Panel Data. Applied Financial Economics 25: 345-356.

41. Engle RF, Granger CWJ (1987) Cointegration and Error Correction: Representation. Estimation and Testing. Econometrica 55: 251-276.

42. Fama EF, French KR (1993) Common Risk Factors in the Returns on Stocks and Bonds. Journal of Financial Economics 33: 3-56.

43. Friedman M (1961) The Lag in Effect of Monetary Policy. Journal of Political Economy 100: 447-466.

44. Friedman M, Schwartz AJ (1963) Money and Business Cycles. Review of Economics and Statistics 40: 52-64.

45. Gibson WE (1970a) The Lag in the Effect of Monetary Policy on Income and Interest Rates. Quarterly Journal of Economics 84: 288-300.

46. Gibson WE (1970b) Interest Rates and Monetary Policy. Journal of Political Economy 78: 431-55.
47. Granger CWJ (1969) Investigating Causal Relationship by Econometric Models and Cross Section Special Methods. Econometrica 37: 425-435.

48. Moore BJ (1988) Horizontalists and Verticalists: The Macroeconomics of Credit Money. Cambridge: Cambridge University Press.

49. Kraft J, Kraft A (1977) Common Stock Prices: Some Observations. Southern Economic Journal. 43: 1365-1368.

50. Kraft J, Kraft A (1977) Determinants of Common Stock Prices in Time Series Analysis. Journal of Finance 32: 417-425.

51. Moore BJ (1989) The Endogeneity of Credit Money. Review of Political Economy 1: 64-93.

52. Moore BJ (1988) Horizontalists and Verticalists: The Macroeconomics of Credit-Money. Cambridge: Cambridge University Press.

53. Parhizgari AM, Duong N (2011) M1, M2 and the US Equity Exchanges. Frontiers in Finance and Economics 8: 112-135.

54. Pesando JE (1974) The Supply of Money and Common stock Prices: Further Observations on the Econometric Evidence. Journal of Finance 29: 909-922.

55. Rochon LP (2006) Endogenous Money, Central Banks and the Banking System: Basil Moore and the Supply of Credit. Complexity, Endogenous Money and Macroeconomic Theory, UK.

56. Ross SA (1976) The Arbitrage Theory of Capital Asset Pricing. Journal of Economic Theory 13: 341-360.

57. Rozeff MS (1974) Money Stock Prices: Market Efficiency and the Lag in Effect of Monetary Policy. Unpublished doctoral dissertation. Graduate School of Management, University of Rochester.

58. Toda HY, Yamamoto T (1995) Statistical inference in vector autoregressions with possibly integrated processes. Journal of Econometrics 66: 225-250 